\title{
DIDACTIC GAMES TO DEVELOP MATHEMATICAL CONCEPTS FOR CHILDREN WITH SPECIAL NEEDS IN KINDERGARTEN
}

Authors:

Tiiu Tammemä $(\mathrm{PhD})$

Tallinn University (Estonia)

Siret Maaring

Special Education Teacher in Counseling Center

(Estonia)

E-mail address of first author:

tiiu.tammemae@tlu.ee
Lectors:

Magdolna Nemes (PhD)

Ferenc Mező (PhD)

Eszterházy Károly University

Tammemä, T., Maaring, S. (2020). Didactic games to develop mathematical concepts for children with special needs in kindergarten. Különleges Bánásmód, 6. (1). 83-93. DOI 10.18458/KB.2020.1.83

\begin{abstract}
Children with developmental disorders do not acquire the same way as do children with an ageappropriate intellectual level, so it needs to be carefully chosen what kind of methods to use and in what way to teach the children. For preschool children, the most efficient and simplest method of teaching mathematics is a playful approach to learning activities. The purpose of this work was to create a set of materials to support the teaching and learning of mathematical concepts for preschool-age children with special needs. There were created learning materials such as Train, Shelves, Long and short, Butterflies and cars, Wide and narrow road, and board game Owls. All the learning materials, including a board game, are laminated and most of them are provided with velcro strips to stick different parts. All the learning materials are tested on preschool-age children and asked specialists and teachers, who work with children with special needs, to give their expert evaluation. Learning materials support teaching mathematical concepts for preschool-age children with special needs.
\end{abstract}

Keywords: special education, special needs in kindergarten, math in kindergarten

Discipline: pedagogy 


\section{Absztrakt \\ DIDAKTIKAI JÁTÉKOK A MATEMATIKAI FOGALMAK FEJLESZTÉSÉRE AZ ÓVODÁSKORÚ, SAJÁTOS NEVELÉSI IGÉNYŰ GYERMEKEK SZÁMÁRA}

A fejlődési rendellenességekkel élő gyermekek nem ugyanazt az utat járják, mint az életkoruknak megfelelő intellektuális szintú gyermekek, ezért gondosan meg kell választani, hogy milyen módszerekkel és milyen módon tanítják őket. Az óvodáskorú gyermekek számára a matematika tanításának leghatékonyabb és legegyszerúbb módszere a játékos megközelítésú tanulási tevékenység.

E munka célja egy anyagkészlet létrehozása, amely elósegíti az óvodáskorú, sajátos nevelési igényú gyermekek számára a matematikai fogalmak tanítását és tanulását. Olyan tananyagokat készítettek, mint például a vonat, a polcok, a hosszú és a rövid, a pillangók és az autók, a széles és keskeny út - és a Baglyok társasjáték. Az összes tananyag (beleértve a társasjátékot is), laminált és a legtöbb tépőzáras szalaggal van ellátva a különböző részek ragasztásához. Az összes tananyagot óvodáskorú gyermekeken tesztelték és sajátos nevelési igényű gyermekekkel dolgozó szakembereket és tanárokat kértek fel a tananyag szakértői értékelésére.

A tananyagok támogatják a matematikai fogalmak tanítását az óvodáskorú, sajátos igényú gyermekek számára.

Kulcsszavak: speciális oktatás, speciális igények az óvodában, matematika az óvodában

Diszciplína: pedagógia

\section{Supporting studying mathematics through the game}

Mathematics play an important role both in a child's life as well as in every adult's. We use it to compare everyday subjects, to orientate in our home, on our body as well as on the streets when remembering the house numbers or phone numbres. It has been found that early knowledge of arithmetics helps to achieve goals in mathematis as well as any other area of life. (Claessens \& Engel, 2013). A person understands the world through mathematics in a very early age and uses it to understand differences and similarities, to create connections and to justify.

Sousa (2001) has brought out that around $6 \%$ of preschool aged children have issues with mathe- matics. As Math play an important role in the development of a child it is important to pay full attention on the difficulties of studying as a child in order to avoid issues that might occur in school when they take the subject more into depth.

Math is studied in the kindergarten integrated with every other exercise and everyday action. A child explores, compares, counts, sorts, explains, finds differences and similarities. Math can be learned through different senses: seeing, hearing, touch and when possible also through smell and tasting (Sikka, 2009). It is very important that teachers use multisensational approach (Clayton, 2003).

Mathematics play an important role in a childs everyday life in the kindergarten. A young child 
my have a hard time understanding symbolic concepts and therefore there are specific aids that are used in teaching: the children can count or hold something in their had that is a symbol. By having something in their hand that can be manipulated a child learns to create abridge between the physical world, symbols and abstract concepts (James, 2016), The mathematics of a kindergarten is based on the so called getting the world in order so that he child can orientate in the surroundings and in the world of items and situations (Sikka, 2009a)

From a cognitive development point of vies it is important that the childs understands the shapes, sizes, patterns and positions of different figures (McCartneu \& Philips, 2006). The development of mathematical skills is based on the development of all senses and specially the visual-spatial sense. This helps the preschool aged children the divide and name items in according to their features, to compare them, the assemble the similar items and to operate with them practically. The perception of the ratio of amount and shape creates a base for understanding the bases of mathematics and numbers (Martinson, 2010).

It is important to associate the the mathematical concepts with everyday exercises, to focus on action and playing. The math in a kindergarten is highly related to acquiring the verbal concepts. It is superficial for children to understand the mathematical concepts early in their development. For example they understand when ,here's more than there“. They understand if „you take from here there's going to be less". Many of this kind of skills develop even between they can speak (Bowman, 2001).

For children with special developmental need it is important in the process of learning to create a purposeful thinking method. The actions created on the purposeful thinking help the children to see the connection between objects as well as they will orient better in the purpose of their actions and in achieving them. As a result their actions become meaningful: they become to forsee the events and understand the relations between when and why (Strebeleva, 2010a).

The developmental needs of children with special needs depend on with the primary need as well the secunday which results from it. When planning an action for the children one must consider their individual specialities as they might need more directing from the teachers compared to their mates to ensure they learn the material.

The acquiring of general knowledge happens effectively though didactic games directed by an adult. To fully support the learning of a child and to offer necessary support the adult needs to detect the actual level of development meaning to find out what exactly the child can do without any help and what the child can achieve with the help of an adult. Solving an exercise independently shows the actual level of development while solving the same exercise in optimal circumstances with the guidance of an adult shows potential level of development.

The difference between these two conditions was called by Lev Võgotski (1896-1934) the zone of proximal development (Krull, 2000).

It is extremely important to understand the zone of proximal development when it comes to teaching children with special needs. In order to create a learning plan for them it has to be taken into account that these children acquire knowledge slower however forget fast - this is why it is recommended to use different methods and techniques that help to activate the audible, visual and kinetic senses. The actual learning only occurs when it is slightly ahead of the actual development of the child.

The skill to sense the objets, to analyse, compare and generalise does not come automatically when doing something - it takes teaching and directing to study and analyse the qualities of objects. Didactic games where the goal is to generalise and rhythm the emotions are of great help in order to specify the images, sizes, the spatial relations and to sepa- 
rate and acquire the sounds (Sakulina \& Poddjakov, 1973).

In order to teach math to a child with special needs it has been found that a playful approach gives the best results as this is the favourable activity for them. It is a great way to lure the child into doing things that normally they might not enjoy. Motor skills for example can also be taught through playing. It is often found that the child gets so carried away by the activity that they do not even grasp that they are learning. This sort of activity however helps to remember things (Reinvart, Klemmer \& Vaas, 2009).

\section{The formation}

\section{of mathematical concepts for a child}

The concept of size, amount, numbers, colors and spatial relations is used in various games Size is relative. The same object can be larger or smaller in compared to other objects. Size can be described by hight, length and width and therefore in addition to the parameters 'large-small' there are also terms like 'long-short', 'high-low' and 'widenarrow' in use. A 3 year old child should only be able to distinguish only by size 2-3 objects by showing which one is bigger or smaller (Kuusik, 2007). A 3-4 year old uses terms like bigger-smaller, longer-shorter, wider-narrower to describe the objects. A 4-5 year old child can put 3 objects in order by size, length, width or hight and can use the terms 'higher-lower' while a 5-6 year old child can put up to 5 objects in order by size and can visually confirm which one is 'bigger-smaller or same size' and will check the results by comparing. It is important to develop the visual measuring skills of a child (Sikka, 2009b)

To combine objects into a quantum means to classify them according to their features. At first only one feature is used for classification, then two and then more than that. Counting is the corner stone of teaching numbers and this is also an everyday activity of any adult. A 2-3 year old child can combine objects by one mutual feature by finding 'the similar' or 'the one'. They can count up to three and can answer the question 'how many'. A 3-4 year old child is able to define if the object belongs to the quantum. By creating pairs the child will find out if there is the same amount of objects in the quantum or not. The child knows the numbers and can count up to five. A 4-5 year old child will combine the objects or creatures by two features (for example boy or girl), will compare the pairs and only then decides if there is more one or the other. 5-6 year olds know the numbers and can count up to twelve. A 6-7 year old knows the numbers up to twelve, knows their order and will confirm the amount of objects by counting them (Sikka, 2009b).

The perception of colour cannot be verified by trial and error, only visual sense can be used. At first the learning of colours will happen by trying and comparing however at the same time the child might not be able to confirm the colour and can only find the similarity or difference. It is difficult to determine the similarities or differences for children with developmental issues. Once a child can determine the colours they will proceed to choosing by a sample and nominating them. The perception of colour is the foundation of sensing colours (Strebeleva, 2010b). A 3 year old child with normal development should be able to name and use 3-4 main colours (Kuusik, 2007),

When speaking of sense of space then usually it is about the objects and their parts located on top, below, on the right, on the left, in front and behind of each other. To orientate in space means to position the object or person from the location of oneself; to position oneself from other objects or people; to position objects from each other (Sikka, 2009b). The space can be divided into closer and farther space. For children with developmental issues the positioning on closer space is easier and 
happens earlier than in farther space. Even for a preschool aged child with normal development it can be difficult to position oneself in space (Strebeleva, 2010b). Therefore is is most important to intervene in supporting the children with developmental issues.

Didactic games is a way of teaching that is lead by an adult and the goal is to acquire the knowledge of the curriculum through play - individually or in a group. Certain conditions are created in didactic games where a child can operate independently in a certain situation with specific objects by gaining a cognitive experience. It is specially important for children with developmental issues as their material actions are weak, not generalised and their attention is not focused on the action (Strebeleva 2010b).

\section{Metodology of research}

The goal of this research was to prepare a set of learning equipment to support the teaching of mathematical terms for preschool aged children with special needs.

Siret Maaring's Master's thesis was to study the development and to prepare learning games to acquire mathematics in the kindergarten - she was supervised by Tiiu Tammemäe, lecturer of special education (Maaring, 2017; Tammemäe \& Maaring, 2019). The games and their applicability was tested on children with special developmental needs. The finished games were tested in kindergartens on children aged 3-7. The sample was a total of 11 children who suffered from attention and activity disorders and backwardness of intellect.

Four specialists were provided the games in to be used and studied and to provide expertise. The specialists were teachers and support specialists who worked with childre.

All the games in this article are created in a way where the teacher can change the level of difficulty epending in the specific near development zone of the child. The applicability of the games was also tested on children with special developmental needs. All the pieces of the games are laminated in order to ensure the durability in repeated use.

It is important to define the specific developmental age of a child with special needs - therefore the biological age or the 'suited for ages' is not relevant for these developmental games. The instructions and specific questions have been added to the games however the content of each mathmetacially developing exercise depends on the child's characteristics and the creativity of the teacher.

\section{Games to support the learning of mathemati- cal terms}

\section{Game 1: the train}

A strip of velcro is fixed on the base board with rails - the player uses the velcro to attach wagons to it as guided by the teacher (Figure 1). The wagons are lined up after each other however the child needs to rearrange them as instructed. This develops attention, thinking and fine motor skills. The child needs to understand that in order to place a wagon they need to rearrange the ones already in place.

Figure 1. The Train (By the Authors)

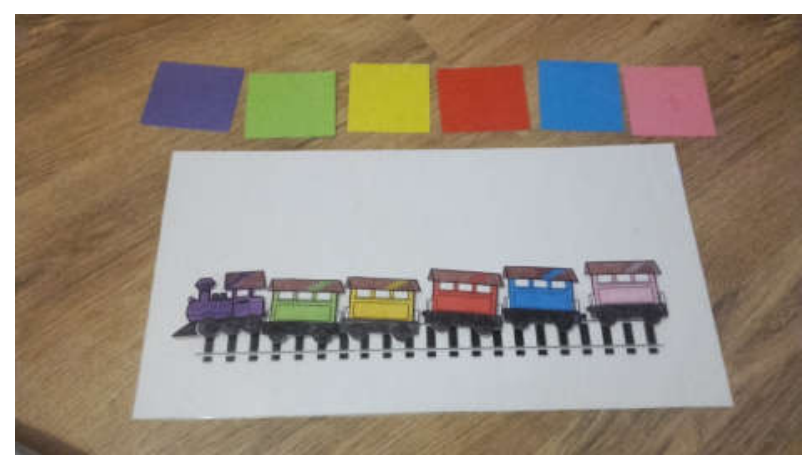




\section{The aim of the game}

- The child knows the terms in front / behind, before / after, in the center / in the middle

- The child knows the ordinal numbers and the terms the first / the last

- The child knows the colours purple, green, yellow, pink, blue and red.

The tools: The board, 5 different coloured wagons, a train, 6 colour cards

\section{The game play:}

Option 1. The teacher introduces the player the tools and explains the game. The train is placedo in the board together with the teacher. The player then starts to place the wagons after the train as instructed.

- Take the purple wagon and place it on the rails at the very front

- Take the yellow wagon and place it behind the train

- Take the green wagon and place it between the yellow one and the train

- Take the blue wagon and place it behind the yellow one

- Take the red wagon and place it behind the blue one

- Take the pink wagon and place it behind the blue one

- The already placed wagons can be rearranged as instruced. Afterwards the teacher can ask additional questions from the player.

- What colour is the first wagon?

- That colour is the wagon behind the blue one?

- What colour is the wagon between the blue and the yellow one?

- What colour is the last wagon?

- That colour is the third wagon?
Option 2.: The teacher places the colour cards on the table that the player will use to start placing the wagons on the board. The same questions can be asked as were used for the first option.

\section{Game 2: Balls in line}

The aim of the game (Figure 2):

- The child knows the patterns dotted and striped

- The child knows and uses the colours red, pink, green, purple and yellow

- The child knows and uses the ordinal numbers first, second, third, fourth

- The child knows and uses the terms in the middle, the first, at the top, above, below, on top

- The child can compare objects by their size

The tools: 8 different coloured and patterned balls, the board with Velcro

Figure 2. Balls in line (By the Authors)

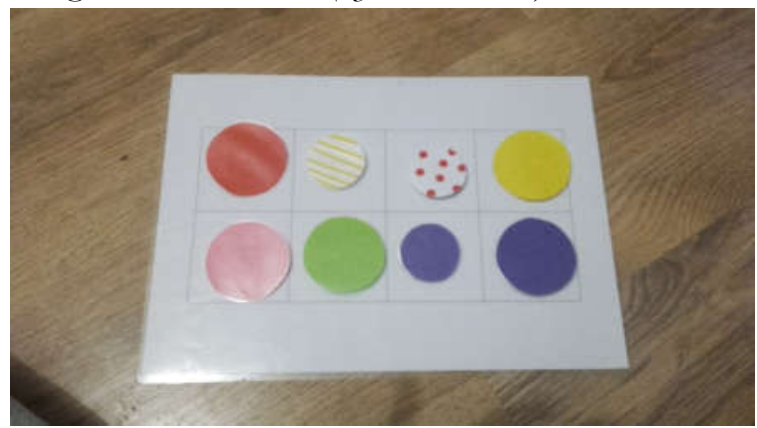

The game play

The player stars placing the balls on the board as instructed.

Put:

- The yellow ball in the last box on the top

- The bog purple ball in the box below the yellow ball 
- The green ball in the second box of the bottom line

- The small purple ball to the right from the green ball

- The yellow striped ball in the box above the green ball

- The red ball in the first box of the top line

- The red dotted ball in the third box of the top line

- The pink ball in the first box of the bottom line

Once the balls are in place the teacher can ask several additional questions (How many balls are in the top/bottom line? How many balls are there in total? What shape are the balls?)

What colour is the ball...

- The first one in the bottom line?

- Between the yellow and the striped one?

- The third one in the top line?

- Between the green and the big purple one?

- Below the striped one?

- Next to the dotted one?

- To the left from the blue one?

- How many balls in the top line?

\section{Game 3: The shelf}

The aim of the game (Figure 3):

- The child understands and uses the terms right/left, top/ bottom

- The child understand and uses the ordinal number first and second

- The child can combine by mutual features/general terms (toys, fruit, vegetables, tools)

- The child can feel tactilely different materials: rough, hairy

The tools: the board with velcro (the picture with 2 shelves), different fruit, vegetables, toys, tools. Models of the right and left hands of different tactile materials.
Figure 3: The Shelf (By the Authors)

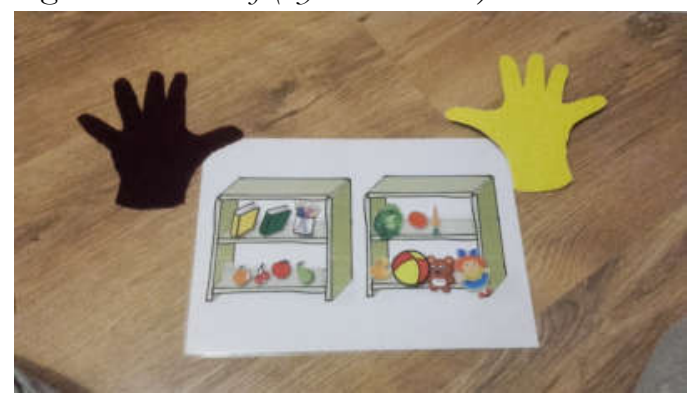

The teacher introduces the models of the hands to the player. The own hands are also studied and which one is right and left is determined. The different surface of the models is felt (rough, hairy)

\section{The game play}

The player will start placing the object in the shelves as instructed by the teacher so that similar objects are combined together (fruit, vegetables, toys, stationary). Once the objects are in the shelves they can be compared with additional questions: which shelf has more/less objects, which objects are in the shelf, which groups have been combined, how many objects are in the shelf etc.

Take...

- ...the ball. Place it on the bottom shelf on the right.

- ...the books. Place them on the top shelf on the left

- ...the cabbage. Place it on the top shelf on the right

- ...the duck. Place it on the bottom shelf on the right

- ...the tangerine. Place it on the bottom shelf on the left

- ...the tomato. Place it on the top shelf on the right

- ...the cherry. Place it on the bottom shelf on the left 
- ...the pencils. Place them next to the books.

- ...the apple. Place it next to the cherry.

- ...the doll. Place it on the bottom shelf on the right

- ...the bear. Place it next to the doll.

- ...the carrot. Place it on the top shelf on the right

- ...the pear. Place it next to the apple.

Additional questions:

- What is on the right side of the top shelf? (general term)

- What is on the bottom shelf on the left?

- What is on the top shelf on the left?

- What is on the bottom shelf on the right?

- How many tings are on the top shelf on the right?

- How many things are on the bottom shelf on the right?

- How many tings are on the shelf on the left?

- Which shelf has the most objects?

\section{Game 4 and 5: Butterflies and Cars}

The aim of the game (Figure 4 and 5):

- The child understands the terms big/small and the superlative the biggest/smallest

- The child can compare the objects by their size

- The child understands and uses correctly the colours green, pink, red, blue, yellow, brown, purple

- The child can use mathematical equations to calculate up to 5 by using additional tools.

Tools: Board with velcro for cars and butterflies, 5 different sized butterflies and cars.

The game play

The child will start to place the butterflies/cars according to the size as instructed by the teacher.
Figure 4. Butterflies (By the Authors)

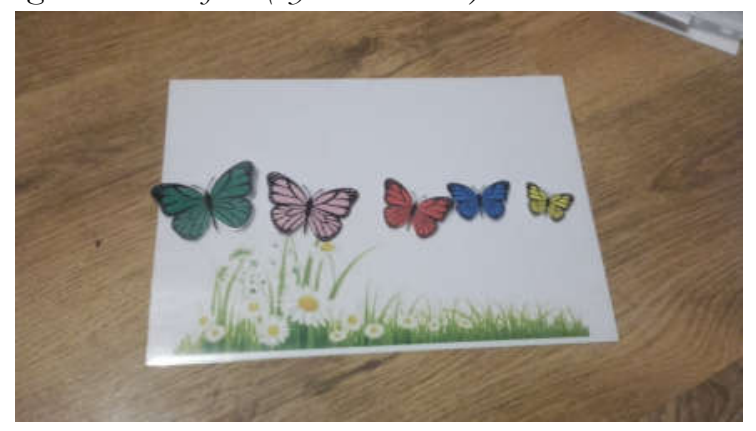

Figure 5. Cars (By the Authors)

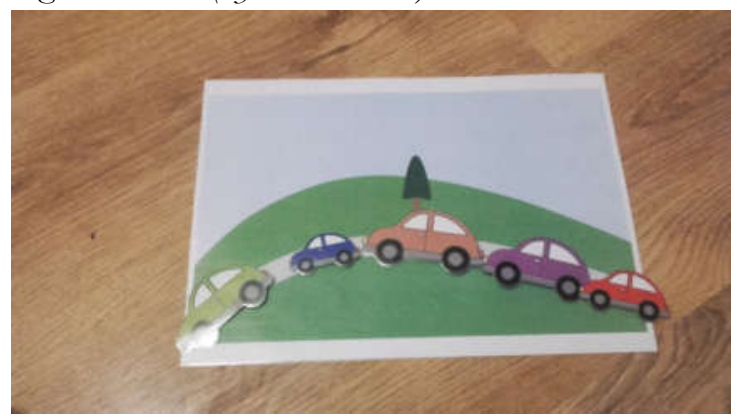

Fore example: take the biggest butterfly and place it as the first. The child can also place the butterflies/cars on the board by size without providing instructions. Afterwards you can check together with the player if the pictures are in correct order. In addition the colours of the butterflies/cars can be mentioned, the objects can be counted, their place in line can be determined, their position in front/ behind/between other objects can be found.

The butterflies:

- Which colour butterlfy is the biggest?

- Which on is bigger: the blue or the yellow butterfly?

- Which one is bigger: the pink or the red butterfly? 
- Which one is smaller: the green or the blue butterfly?

- Which one is smaller: the red or the yellow butterfly?

- What colour is the butterfly next to the yellow one?

- What colour is the butterfly between the pink and the blue one?

- How many butterflies are there in total?

- How many butterflies will be left after 2 fly away?

- How many butterflies will there be if one more arrives?

Cars:

- What colour car is the biggest?

- What colour car is the smallest?

- Which one is bigger: the blue or the green car?

- Which one is bigger: the brown or the purple car?

- Which one is smaller: the green or the blue car?

- Which one is smaller: the red or the blue car?

- What colour is the car in front of the blue one?

- What colour car is between the purple and blue cars?

- How many cars are there in total?

- How many cars will there be left if one drives away?

- How many cars will there be if one more arrives?

\section{Game 6: the wide and the narrow road}

The aim of the game (Figure 6.)

- The child understands the terms wide/narrow and knows how to use them
- The child understands the positions on top, above, next to and knows how to use them

- The child compares quantities

- The child can count up to 10

Figure 6: The wide and the narrow road (By the Authors)

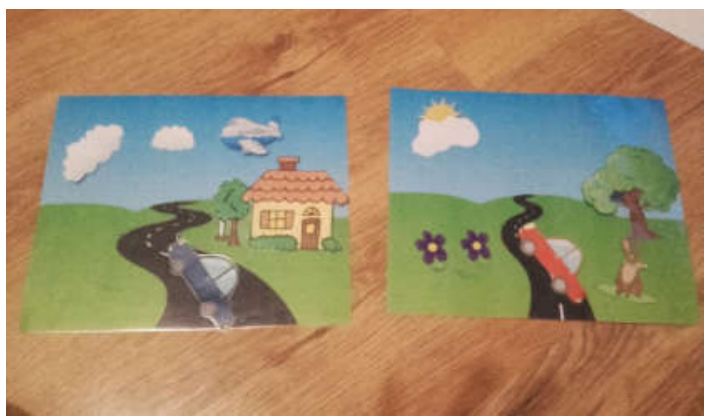

Tools: Boards, different objects to be placed (flowers, plane, house, tree, cars etc.)

The game play

The teacher introduces the game and the boards to the player that are then compared. The child will start placing objects on the board with the wide and narrow road as instructed.

- Take the house. The house is by the wide road.

- Take the flowers. The flowers grow by the narrow road.

- Take the sun. he sun shines in the sky above the narrow road.

- Take the clouds. The clouds lay in the sky above the wide road.

- Take the plane. The plane flies in the sky above the wide road.

- Take the rabbit. The rabbit is next to the narrow road.

- Take the red car. The red car drives on the narrow road. 
- Take the blue car. The blue car drives on the wide road.

- Take the tree. The tree grows next to the wide road.

After the objects are placed they can be counted as per how many were placed on one board or the other. Where is more / less objects?

Additional questions

- Name the objects that you placed on the board with the narrow road.

- Name the objects that you placed on the board with the wide road

- How many objects did you place on the board with the narrow road?

- How many objects did you place on the board with the wide road?

- Which board has more objects?

- Which board has less objects?

- Name the objects that you placed next to the narrow road

- Name the objects that you placed next to the wide road

\section{Game 7: Owls}

The aim of the game (Figure 7)

- The child knows and understands the main colours

- The child knows and uses the ordinal numbers

- The child knows and implements the positional terms in front, bebind, in the middle, the first, the last, the top, the bottom

- The child compares objects by size and length

- The child groups the objects by mutual features
Tools: The board (tree with owls), blue and red function cards, game pieces (4 owls), dice.

Figure 7. Owls (By the Authors)

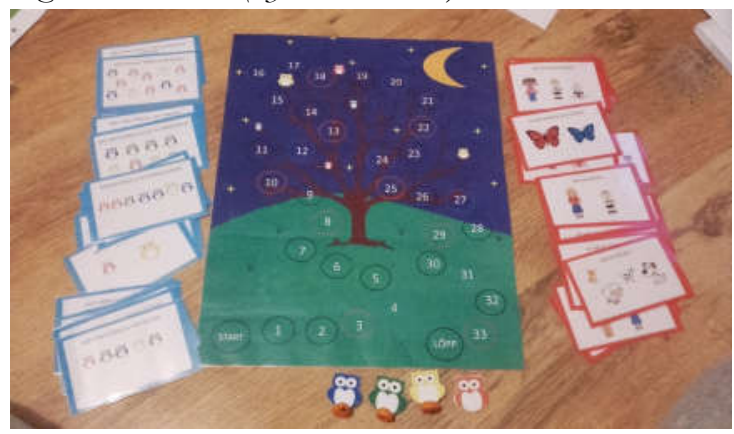

The game play

The board game is meant for 2-4 players.

All pieces are placed on the 'start' area of the board. The first player is determined by draw. The player takes steps according to the roll of the dice. When the player ends up on the red or on the blue field, a function card is drown, it is read out loud and the question needs to be answered. If the answer is right, the player gets to stay on the same place, if the answer is wrong the player needs to take one step back.

Figure 8. Owls extra cards(By the Authors)

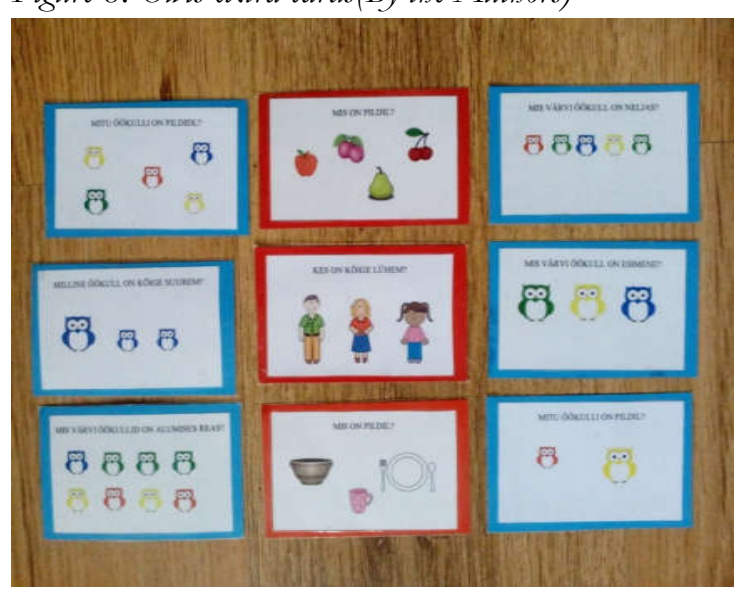


The questions on the function cards are about counting, grouping, positioning, ordinal numbers, comparing, colours and sizes. For example:

- Who is taller? The boy or the girl?

- What colour is the third owl?

- What is on the picture, name it with one word (general term!)

- Show me which owl is the biggest

- Show me who is the shortest

- What colour is the first owl?

- What colour are the owls in the bottom line?

The player who rolls the exact amount of steps on the dice wins the game.

\section{The summary}

Mathematics is all around us and is necessary throughout our lives. Mathematical knowledge and skills are one of the bases to develop other skills and knowledge. Early knowledge of mathematics help children to develop both mathematical and other life skills as they grow up (Claessens \& Engel, 2013). It is important to support children who struggle with mathematics as early as possible. Playing has an important role in the development of a child therefore it is recommended to approach teaching mathematics through playing as is suggested in the examples of this article.

It can be concluded by the expertise and experience in teaching that the games here support the curriculum and the mathematical learning purposes in the kindergarten. The experts also concluded that the games help to diversify the learning activities, the instructions are clear and the aims of the games are achievable.

\section{References}

Bowman, B. T. \& Donovan, S. M. \& Burns, M. S., (2001). Eager to Learn: Educating Our Preschoolers. Washington, DC: The national academies press
Claessens, A \& Engel, M. (2013). How Important Is Where You Start? Early Mathematics Knowledge and Later School Success. Teachers College Record, 6, 115.

Clayton, P. (2003). How do develop numeracy in children with dyslexia. England: LDA

James, A. (2016). What to Expect in Kindergarten Math.

https://www.education.com/magazine/article/ Kindergarten_math/

Krull, E. (2000). Pedagoogilise psühboloogia käsiraamat. Tartu: Tartu Ülikooli kirjastus /Handbook of Pedagogical Psychology/

Kuusik, Ü. (2007). Arendustegevus ja sekkumine enne lapse 3. sünnipäevaEripedagoogika: alusharidus. 27, 22-28.

/Development and intervention before the child's 3rd birthday/

Maaring, S. (2017), Õppevahendite komplekt matemaatiliste mõistete omandamiseks arenguliste erivajadustega lastele, Tallinna Ülikool, Haridusteaduste instituut. (Master's thesis) /A set of educational tools for acquiring mathematical concepts for children with special educational needs/

Martinson, M. (2010). Opirakused: Kelle probleem? Kust otsida lahendusi?. Tallinn: Koolibri

/Learning Difficulities: Whose Problem? Where to look for solutions?/

Mcartney, K. \& Phillips, D. (2006). Blackwell handbook of Early childhood development. Blackwell Publishing

Reinvart, M. \& Klemmer, G \& Vaas, R. (2009) Matemaatika õpetamine läbi integreeritud tegevuse. Eripedagoogika: Matemaatika 2. osa, $\mathrm{nr}$ 32./Teaching mathematics through integrated activities/

Sakulina, N. P. \& Poddjakov, N. N. (1973). Sensoorse kasvatuse osa lasteaia õppe- ja kasvatustöödes. Rmt. Sensoorsest kasvatusest lasteaias. Tallinn: Eesti NSV Haridusministeerium/The role 